\title{
When Good Girls Go Bad (Or Do They?): Nymphomania and Lycanthropy in Verga's "La Lupa”
}

Ilona Klein

Brigham Young University - Provo, ilona_klein@byu.edu

Follow this and additional works at: https://scholarsarchive.byu.edu/facpub

Part of the Italian Language and Literature Commons, and the Women's Studies Commons

\section{Original Publication Citation}

Klein, Ilona. "When Good Girls Go Bad (Or Do They?): Nymphomania and Lycanthropy in Verga's "La Lupa"." MLN, vol. 134 no. 6, 2019, p. S-272-S-285. Project MUSE, doi:10.1353/ mln.2019.0072.

\section{BYU ScholarsArchive Citation}

Klein, Ilona, "When Good Girls Go Bad (Or Do They?): Nymphomania and Lycanthropy in Verga's "La Lupa"' (2019). Faculty Publications. 3963.

https://scholarsarchive.byu.edu/facpub/3963

This Peer-Reviewed Article is brought to you for free and open access by BYU ScholarsArchive. It has been accepted for inclusion in Faculty Publications by an authorized administrator of BYU ScholarsArchive. For more information, please contact ellen_amatangelo@byu.edu. 


\title{
When Good Girls Go Bad (Or Do They?): Nymphomania and Lycanthropy in Verga's "La Lupa"
}

\author{
Ilona Klein*
}

At some point during early development, most children are afraid of the imaginary wolf under the bed or the wolf that hides in the closet at night. Traditional bedtime stories such as Little Red Riding Hood certainly do not help assuage such fears: these are atavistic dreads, similar to being scared of the dark or of death. ${ }^{1}$ In childhood culture, the wolf represents the "other," the "furry non-human," and almost always the viciously violent. Later, as adults, the occasional dream of wolverine violence, or of human transformation into a wolf (a lycanthropic aversion) might very well create anxiety and apprehension. ${ }^{2}$ Over the centuries, Western people have learned to negotiate their innate fear of wolves by capturing them, dominating them, and, in many locations, bringing them almost to the brink of extinction. It seems, then, that humans' raw fear of the wolf eases when they can safely observe the animals from afar, confined to a cage or a managed

\footnotetext{
*My appreciation goes to Madison Sowell, Whitney Call, and another reader who provided me with feedback on a previous version of this study.

${ }^{1}$ With his historical interpretations of Little Red Riding Hood, Jack Zipes points the reader to the fable's message: women are supposed to stay on their designated path, for if they stray, they are asking for it ("it" meaning sex-in other words, asking to be sexually assaulted). See Zipes, ed., Trials, 1-15 and 17-90.

${ }^{2}$ To clarify the terms I use in this study, lykantropia, from lykos ("wolf") + anthropos ("man"); and werewolf, "person with the power to turn into a wolf."
} 
roaming pen. In this case, the observer, now protected from the "savage beast" behind bars, perceives the wolf as controlled and tamed. The truth of the matter, of course, lies in the illusion that the wild has been stamped out of the captive wolf. Tellingly, at the same time, the very need to trap the wolf implicitly validates the wolf's superior physical strength and affirms its powers over humans.

Canonical Italian literature offers one important example of a tamed wolf. Chapter 21 of I Fioretti di San Francesco recounts the much beloved and inspirational story of Saint Francis of Assisi who searches the countryside for a very large, terrible and ferocious wolf ("uno lupo grandissimo e terribile e feroce"),${ }^{3}$ demanding that it stop terrorizing the town of Gubbio, and requesting its promise to do so ("Promettimi tu questo?”). ${ }^{4}$ The wolf, now turned obedient, trusting and no longer aggressive, peacefully puts its large paw into Saint Francis's extended hand. The two return to the village, as the wolf shows submission and deference, kneeling and lowering its head to prove its fidelity and commitment ("E il lupo, inginocchiandosi e inchinando il capo e con atti mansueti . . . dimostrava ... di volere osservare loro ogni patto"). ${ }^{5}$ As a reward for its obedience, the residents now invite it into their homes and glady feed it whenever it is hungry. Two years later, well integrated into the village's life, "Brother Wolf" dies of old age, mourned by all ("e fu nutricato cortesemente dalle genti. . . . Finalmente dopo di due anni frate lupo si morì di vecchiaia. Di che i cittadini molto si dolevano"). ${ }^{6}$ While at first blush the legend of the wolf of Gubbio shows a happy and peaceful ending, in reality the reason why the wolf can coexist with the villagers is because its own, innate wild nature has been altered into acquiescence and compliance to the will of humans (albeit inspired by faith, humility and brotherly love) rather than dignifying its own biological existence. If wolves were to roam free and attack unarmed humans, the humans would inevitably lose the fight.

At first glance, it would appear that Gnà Pina, the protagonist of Giovanni Verga's short story "La Lupa" (1879), follows the fate of the wolves' marginalization and ultimate annihilation. Gnà Pina is feared by the villagers as an instinctual wild she-wolf looking for prey, hence the reason for her nickname. She roams the streets, her apparent uncontrollable sexuality free to victimize the men in town, ravaging

${ }^{3}$ Francis of Assisi, "Capitolo XXI," 69.

${ }^{4}$ Francis of Assisi, "Capitolo XXI," 71.

${ }^{5}$ Francis of Assisi, "Capitolo XXI," 72.

${ }^{6}$ Francis of Assisi, "Capitolo XXI," 73. 
her casualties (according to the villagers' lore) until-at least at a cursory reading of the short story-it appears that Nanni finishes her off with his axe at the end of the narrative.

This study looks at Verga's "La Lupa" and highlights the consequences of Gnà Pina's sexual freedom in the short story, and within the frame of a traditional patriarchal society such as Sicily during the late 1800s. Verga's short story manages to encapsulate in less than a handful of pages the cultural, mythical, and anthropological heritage of the symbol of the she-wolf and the echoes connected to the ancestral fear of werewolves. Also, this study looks at reinterpreting some of the traditional negative Western lore on the wolf by dignifying the animal's biological existence. Through this viewpoint, perhaps the vicissitudes of Gnà Pina might also enjoy a newfound literary triumph, as the interpretation of the short story is freed from its narrative patriarchal chains. At that moment, then she-wolf Gnà Pina could be validated to roam freely in her own sexual space. Must she continue to be trapped in the eyes of the reader by following Verga's own narrative of Sicily's cultural perceptions, and must she be violently murdered, as the apparent end of the short story seems to imply?

The main problem at the core of "La Lupa" necessarily points to the sexualization of power and to the power of sexuality. In either case, the rapport with traditional societal expectations has been inverted in Verga's short story, because here it is the woman, rather than the man, who is openly sexualized. This behavioral inversion creates the main tension of the short story.

Of course, one cannot discuss any Italian author who writes about she-wolves without first recalling the legend of "la lupa capitolina," the she-wolf symbol of Rome. Her myth is well known: Rhea Silvia (the daughter of Numitor, former king of Alba Longa), a virgin princess raped by Mars, the god of war, gives birth to twins, Romulus and Remus. Abandoned by the servants of an uncle (Amulius) along the banks of the Tiber River, the babies are saved by a lactating she-wolf on Rome's Palatine Hill. Eventually, Romulus assassinates his brother, Remus-an act of violence that echoes the true nature of these feral children. The legend gives Numitor (and thus Rhea Silvia) a direct genealogical descent from Aeneas, through eleven previous generations. ${ }^{7}$ The myth of the birth of Rome explains why the she-wolf is sacred to Mars. Still, today, when wandering about Rome, one is surrounded by emblems of "la lupa," an iconography that permeates 
Rome's urban landscape (on street water fountains, on urban buses, etc.). Within the myth, "the nursing she-wolf abbreviates the distance between humans and animals."

The word "lupa" also evokes a meaning different from that of the Latin lupa ("she-wolf"), the feminine form of lupus ("wolf"). By association, in ancient Rome and in Pompeii, brothels were called "lupanari," to indicate the place where human "she-wolves" met to sell sexual favors to their clients. Given this linguistic etymological twist, "the she-wolf who rescued Mars's twins may have been a local hooker who practiced in the great outdoors"9 - and perhaps both in the great outdoors and in an actual enclosed house of prostitution. According to Lactantius and St. Augustine, the she-wolf was indeed a prostitute. ${ }^{10}$ Archeologists are currently excavating the ancient site of the houses of prostitution in the Roman Forum where the she-wolf's cave was located, a site that was a well-known shrine in antiquity. The whore-houses in ancient Roman cities were called "i lupanari," and women with high sexual drive are still known today in Italian street jargon as "allupate." Be that as it may, Rome's "lupa" represents both a nursing mother (the she-wolf who suckled Romulus and Remus) and a lusty prostitute. She is a good (surrogate) mother, for she did rescue the twins, but at the same time she is symbolically connected to

\footnotetext{
${ }^{8}$ Mazzoni, She-Wolf, 7.

${ }^{9}$ Mazzoni, She-Wolf, 160.

10"Porro Amulius fratris sui Numitoris filiam Rheam nomine, quae etiam Ilia uocabatur, Romuli matrem, Vestalem uirginem fecerat, quam uolunt de Marte geminos concepisse, isto modo stuprum eius honorantes uel excusantes, et adhibentes argumentum, quod infantes expositos lupa nutriuerit. Hoc enim genus bestiae ad Martem existimant pertinere, ut uidelicet ideo lupa credatur admouisse ubera paruulis, quia filios domini sui Martis agnouit; quamuis non desint qui dicant, cum expositi uagientes iacerent, a nescio qua primum meretrice fuisse collectos et primas eius suxisse mamillas (meretrices autem lupas uocabant, unde etiam nunc turpia loca earum lupanaria nuncupantur), et eos postea ad Faustulum peruenisse pastorem atque ab eius Acca uxore nutritos." ("Amulius, moreover, had made his brother Numitor's daughter, named Rhea (who was also called Ilia, the mother of Romulus) a Vestal virgin. Men claimed that she conceived twins of Mars, and in this way they honour or excuse her lapse from chastity, and offer as a proof that a she-wolf nursed the infants when they were exposed. For they think that this sort of animal belongs to Mars, and hence the she-wolf is believed to have offered her dugs to the little ones for the reason that she recognized them as the sons of her master Mars. And yet men are not lacking who say that when the exposed infants lay wailing, they were first rescued by an unidentified harlot, and that her breasts were the first to suckle them-for indeed they called harlots she-wolves, for which reason even now houses of ill-fame are called lupanaria, meaning den of wolves-and that later they came into the hands of the shepherd Faustulus and were nursed by his wife Acca.") Original Latin and English translation from Augustine of Hippo, City of God 18.21. See also Lactantius, Divinarum Institutionum 1.20. My thanks to Christopher Kleinhenz who pointed out to me the Lactantius and St. Augustine references.
} 
a sexually charged being. In her book, Cristina Mazzoni perceptively highlights the she-wolf's triple nature of "mother, beast and whore."11

Men (i.e., human males), thus, are conflictingly attracted to and afraid of the she-wolf. "The human she-wolf's teats may feed but her breasts enslave. Her tongue can give shape . . but, in other circumstances, it is an instrument of pleasure too. The problem is that one can never be sure of the she-wolf's intentions or of what she plans to do with her breasts and her tongue." 12 To emphasize this dual, ambiguous nature of the "lupa," the gaze of the she-wolf in iconographic representations is usually not fixed on the babies she is suckling but on those watching her. Famous examples, to mention a few, include the bronze statue of the Lupa Capitolina in the "Sala della Lupa" of the Musei Capitolini in Rome and the marble statue of the she-wolf in the Museo dell'Opera del Duomo in Siena. Just as any wild animal would behave in its own environment, the she-wolf is fierce, suspicious, cautious, and attentive at all times to her surroundings.

In Verga's short story, Gnà Pina is symbolically caged, confined to the pages of the novella. Due to this coercion, her animal-like, lusty self might appear to be less of a threat to the bourgeois readership of Italy's verismo and less of a threat as a predator to people, because, zoologically, wolves follow a patriarchal pack-hunting order. But is this assumption true?

The she-wolf has historically been connected to an allegory of excessive female sexuality. One of the best and most obvious examples, of course, can be found in Dante's Divine Comedy, where the she-wolf's symbolism has been interpreted as one of incontinence, representing greed, avarice, and undisciplined lustful desires. Dante did not start-but rather followed-an already-established cultural tradition when he placed his literary "lupa" in the Divine Comedy. Virgil (who in the fourteenth century was already long dead, as he accompanied Dante through Hell and parts of Purgatory) is not afraid of the shewolf. Her carnal temptations no longer threaten him. Dante, the medieval, carnal male who is still very much alive, is terrorized by the approaching beast (Inf. 1.49-60). "Oblivious to death because he is already dead, Virgil does not notice the she-wolf; neither does he fear her presence because he has survived death through his poetry." 13 Wolves are feared only by their potential prey. If there are no victims in the vicinity, wolves and she-wolves may roam freely without causing

\footnotetext{
${ }^{11}$ Mazzoni, She-Wolf, 158.

${ }^{12}$ Mazzoni, She-Wolf, 27.

${ }^{13}$ Mazzoni, She-Wolf, 125.
} 
dread, as in Virgil's case. On the other hand, Nanni (in Verga's short story) dreads his encounters with she-wolf Gnà Pina as much as Dante is terrorized by his encounter with the infernal beast.

Human cultural narratives have long included the terrors of the imaginary powers of werewolves, their myths, and their female counterpart, the she-wolves. This inclusion underscores the "transformation from human to animal . . . the theme of the 'beast within' man." ${ }^{14}$ In Greek mythology, Zeus transformed Lycaon into a wolf. The werewolf represents a behavioral archetype. It is a metaphor for polyvalent incarnations of fear inside the human mind. At the same time, it embodies the "self" versus the "other"-the wolf belonging to untamed nature yet very much present as part of human culture. Freud defined it as the beast within: the werewolf as the projection of a psychoanalytic concept; according to the theory of the Freudian unconscious, werewolf legends arise due to unfulfilled desires. Once these desires are fulfilled, there is no longer a need for the metamorphosis of the beast, because some form of syncretism of the human and the animal has been achieved (Bourgault 41). ${ }^{15}$ Since the sixteenth century, the lycanthropic fear turned into ecclesiastical and moral business as well. Because female werewolves were constructed as diabolical, "unnatural mothers" (Bourgault 49) and often viewed, like their male counterparts, as sexual predators, Western European Christian churches took upon themselves the inquisition of the phenomenon, emphasizing the supernatural aspects of it, rather than searching for possible psychological or psychoanalytical explanations.By the 1880s, European literary naturalism and its corresponding Italian movement called verismo had become almost obsessed in perfecting a narrative style that could portray the surrounding landscapes, people, dialects, poverty, and human tragedies objectively and photographically, similar to the way a journalist reports on facts. Chantal Bourgault points out that European romantic lore included a secret admiration for the werewolf and its retreat back into the woods to protect itself from the damage of an industrialized civilization. Romantics, moreover, were keenly attracted to the superstition of the werewolf because of the supernatural poetic inspiration it was believed to offer. The dreadful behavior of the beast could be violent and murderous and, at the same time, involve a savage, sexual aspect to it.

There was a socio-political undertone to this myth, as Bourgault further explains that werewolves were seen as a "threat emanating

${ }^{14}$ Jorgensen, "Lycanthropy," 24.

${ }^{15}$ Bourgault du Coudray, Curse, 14. 
from the underclass." 16 She describes the underclass as a working class of degenerates, where women's sexuality and corporality lacked the aristocratic sophistication necessary to be part of the coeval bourgeoisie. Further deepening fin-de-siècle political anxieties, by the end of the nineteenth century women were demanding the right to vote, expressing their own sexuality more freely, and presenting a threat to the male establishment. Most female werewolves written about in the nineteenth century were depicted as "beautiful . . f femmes fatales . . . emerging . . . to enchant the unlucky man." ${ }^{17}$ In other words, during Verga's lifetime, women were shaking off the chains of past cultural expectations. Upper-class women were organizing groups fighting for equality and human rights, joined by working women interested in clarifying their situation and their children's situation in factories. Even though the farming women, who labored hard in the countryside, were mostly precluded from these urban social movements, they too caught the echoes of the new freedom that city socialites and factory women were hoping for, and the responsibilities that came with this freedom. Some female field laborers began to own their own modest dwellings. Others raised their children single-handedly, without a male presence in the home. Others broke the bonds of sexual repression and cultural expectation and freely fulfilled their own sexual desires. In a reference that specifically addresses Verga's short story "La Lupa," Mazzoni points out that "Pina's beastly character, moving relentlessly between containment and escape, could be read as a metaphor for every human self, for our vacillation between social dictates and bodily desires." 18

In fact, the main theme of Verga's "La Lupa" revolves around a traditional, patriarchal expectation of female sexuality in the nineteenth century and the way that expectation was shattered through Gnà Pina's behavior. Without question, Gnà Pina is defined by the author as a female lycanthropic subject (her nickname, after all, is "la Lupa"). As a Sicilian female who seeks to satisfy her own carnal pleasures, in Verga's short story she becomes the scapegoat of men's surrender and is framed as the one at fault, the woman who destroys the souls of the men on whom she preys. Her nickname and sexual intemperance neither celebrate nor indicate positive feminine accomplishments. Quite to the contrary, they purposefully incriminate her human, sensual, Mediterranean womanhood.

\footnotetext{
${ }^{16}$ Bourgault du Coudray, Curse, 45.

${ }^{17}$ Bourgault du Coudray, Curse, 47.

${ }^{18}$ Mazzoni, She-Wolf, 250.
} 
Until recently, a woman manifesting a strong sexual drive was labeled a "nymphomaniac." According to the American Psychological Association's (APA) Dictionary of Psychology, the definition of "nymphomania" reads as follows:

$n$. excessive or uncontrollable desire for sexual stimulation and gratification in a woman. The word is often used loosely to denote a high degree of sexuality in a woman, reflecting negative cultural attitudes toward female sexuality and male fears of being unable to meet the sexual needs of women. ${ }^{19}$

However, the 2013 edition of the Diagnostic and Statistical Manual of Mental Disorders (DSM-5), the ultimate psychiatric reference source, does not list nymphomania as a sexual pathology. In fact, the word nymphomania does not even appear in the 947-page volume. What used to be labeled as nymphomania (a term no longer considered an acceptable psychological or psychiatric diagnosis in the United States) would today be classified under some sort of more generalized "behavioral disorder." And, as with all behavioral disorders, sexual or otherwise, it would be considered a pathology only in a case when, subjectively, the female patient felt that her lifestyle was being disrupted by such disorder-in this case, a hypersexual desire..$^{20}$

Works treating nymphomania tend to reveal less about nymphomania itself and more about societal attitudes towards women's sexuality. In traditional patriarchal societies, a sexually assertive (or even sexually aggressive) woman was often patronizingly labeled as a "slut," "nympho," or "lupa" (as in Verga's case). The main point is that a sexually free woman posed a threat to society because she could sap men's sexual energy with her perceived "insatiable" desires. Moreover, so-called nymphomaniacs were widely rumored to take on more aggressive male positioning during intercourse, both socially and sexually threatening the traditional male dominant position. The nickname "la Lupa" given to hypersexual protagonist Gnà Pina might be quite predictable, given some of the literary and mythological symbols discussed at the beginning of this study. For centuries in traditional Western cultures, women have been judged according to standards stemming from conventional social, ethical, religious, moral, national, ethnic and regional conventions, and spanning the entire gamut from chaste and reserved Madonna-saints to sexually insatiable and

\footnotetext{
19“Nymphomania," APA Dictionary.

${ }^{20}$ The corresponding term for a sexually insatiable male would be "satyriasis," a symptom hardly ever discussed, even in academic discourse. There is a double standard in Western society when assessing male and female sexuality, a "locker room talk" of sorts.
} 
promiscuous temptresses preying upon unsuspecting males. According to Carol Groneman, while Western women have historically been held responsible for controlling male sexuality, at the same time they have been expected to model examples of sexual self-restraint or purity. It is clear from the very beginning of the short story into which category of female patriarchal stereotypes "la Lupa" falls.

Verga's short story begins:

Era alta, magra; aveva soltanto un seno fermo e vigoroso da bruna e pure non era più giovane; era pallida come se avesse sempre addosso la malaria, e su quel pallore due occhi grandi così, e delle labbra fresche e rosse, che vi mangiavano. Al villaggio la chiamavano la Lupa perché non era sazia giammai-di nulla. ${ }^{21}$

In her fascinating and meticulously researched work on the werewolf, Bourgault clarifies that-during the scientific and rational period of the Enlightenment and during the second part of the nineteenth century (Verga's own cultural milieu) - the werewolf was studied as a medical phenomenon. It was the medical profession of the nineteenth century (almost exclusively male dominated) which helped legitimize the long-standing diagnosis of nymphomania, one that targeted the perceived "oversexed" female and scapegoated her morally and medically. Physicians believed that many "female diseases" found their origin in the ovaries or in the uterus (the diagnosis "hysteria" immediately comes to mind here).$^{22}$ Moreover, as the medical understanding of hereditary traits became somewhat more sophisticated during the second half of the nineteenth century, it was speculated that "immoral traits acquired in one generation [may be] passed on to the next generation and [become] innate from then on. Supposedly, daughters and granddaughters could inherit-much like blue eyes or brown hair-a nymphomaniac's abnormally carnal traits." ${ }^{23}$ Verga seems to latch onto this belief when he writes that "Maricchia [la Lupa's daughter], poveretta, buona e brava ragazza, piangeva di nascosto, perché era la figlia della $L u p a$, e nessuno l'avrebbe tolta in moglie." ${ }^{24}$ The eligible men in the village feared that she, too, might turn out like her oversexed, insatiable mother.

Shortly after the publication of Verga's "La Lupa" in Vita dei campi

${ }^{21}$ Verga, "La Lupa,” 186.

${ }^{22}$ From the Greek hystera ("womb") comes the word "hysteria"-a nervous disease originally defined as a neurotic condition peculiar to women and thought to be caused by a dysfunction of the uterus. See "Hysteria," Online Etymological Dictionary.

${ }^{23}$ Groneman, Nymphomania, 19-20.

${ }^{24}$ Verga, "La Lupa," 186. 
in 1880, early twentieth-century medical establishments shifted their understanding of where this kind of purported sexual dysfunction resided, and psychologists-also following Freud's first studies-theorized that nymphomania was seated in the brain, not in the genitals, since ovariotomies did not seem to relieve the symptoms. Nevertheless, most physicians looked at the so-called nymphomaniac as a temptress, rather than as a victim of mental circumstances, and were still unable to recognize societal influences that emphasized female passivity and quiet acceptance. The truth is that "sexualized women challenged conventional notions." ${ }^{25}$ By the beginning of the twentieth century, several groups were similarly condemned for their so-called abnormal pathological sexuality, including prostitutes, lesbians, nymphomaniacs, and, eventually, suffragists, feminists, political radicals, and working women-Gnà Pina "la Lupa" is both a working woman and a carnal one. Thus, nymphomania resides—as Groneman puts it— "in the eye of the beholder."26 "La Lupa's" dark eyes and darker skin complexion ("da bruna") fit the stereotypical nymphomaniac. ${ }^{27}$

Famously, Alfred Kinsey, one of the most respected sexologists of the twentieth century, casually defined a nymphomaniac as "someone who has more sex than you do." ${ }^{28}$ In patriarchal societies, it is more convenient for the status quo to point fingers at the so-called oversexed woman than admit that for every oversexed woman, there is also a man who might find himself in her path and who will sexually consume his opportunity.

How does this societal accusation against non-canonical female sexual assertion and independence manifest itself in Verga's "La Lupa"? In patriarchal nineteenth-century literature, fallen women often "pay for their sins by dying at the end of the story." ${ }^{29}$ But does "la Lupa" die?

Before answering this question, let us turn again to Pina's nickname, "la Lupa," and investigate the deeper connections between Verga's protagonist and the literary archetype of werewolves, be they male or female. The first official writings discussing werewolves (i.e., lycanthropy), according to Jane Davidson, began appearing in the sixteenth century. Davidson writes that all of the documents dealing with female lycanthropy are connected to witchcraft and the trials of

\footnotetext{
${ }^{25}$ Groneman, Nymphomania, 30.

${ }^{26}$ Groneman, Nymphomania, 70.

${ }^{27}$ Incidentally, a similar iconography will later be exploited by the Nazis to warn of the "Jewess temptress" eager to conquer sexually the unsuspecting young, blond, German-Aryan man. See Rapaport, "Profaning."

${ }^{28}$ Kinsey qtd. in Groneman, Nymphomania, 90.

${ }^{29}$ Groneman, Nymphomania, 85.
} 
the so-called witches. In the sixteenth century, Europeans truly believed in werewolves - they were not just a fiction of popular imagination. Usually, lycanthropic narratives included werewolves superimposed with-and recognized as-the devil, and multiple etchings from the seventeenth and eighteenth centuries actually show a visual meshing of werewolves and devils. The so-called witches were iconographically portrayed either as allied with other werewolves or the devil (with whom they prepared pacts), or as werewolves themselves. Kathryn Holten writes that "the werewolf's transformation from human to animal underscores the theme of a 'beast within' man . . . where . . . simmering violence [erupts] in erotic insanity." 30 Verga's "la Lupa" is portrayed as a sex-driven woman who manifests mental instability. This is not all that she is; the short story places no emphasis on the strength that she exhibits in raising her daughter, Maricchia, by herself, or on the fact that "la Lupa" actually owns the home where she lives with her daughter-a fact unheard of among the lower agricultural working-class Sicilian women of the time, as virtually no peasant woman owned any kind of real estate in Verga's Sicily. "'Cosa gli date a vostra figlia Maricchia?' rispose Nanni. 'Essa ha la roba di suo padre, e dippiù io le dò la mia casa." "'1

When the incestuous relationship with her son-in-law is discovered and "la Lupa" is asked to leave the home, "No!' rispose però la Lupa al brigadiere. 'Io mi son riserbato un cantuccio della cucina per dormirvi, quando gli ho data la mia casa in dote. La casa è mia. Non voglio andarmene." "32 Verga's "la Lupa" has worked hard in the fields, just like a man would, to obtain some financial independence through ownership of her own home. She "andava nei campi, a lavorare cogli uomini, proprio come un uomo, a sarchiare, a zappare, a governare le bestie, a potare le viti. . .." ${ }^{33}$ Besides her real estate ownership, it is her lifestyle that sets her apart, as it is unconventional and unacceptable for the cultural traditions of the villagers; she works in the fields and roams the village streets "in quell'ora fra vespro e nona, in cui non ne va in volta femmina buona." 34 In contrast to the short story's main narrative line, which attempts to force her character into a simple, oversexed woman driven by carnal pleasure, "la Lupa" Gnà Pina proves to be a strong, independent, unconventional woman who,

\footnotetext{
${ }^{30}$ Holton, qtd. in Jorgensen, "Lycanthropy," 25.

${ }^{31}$ Verga, "La Lupa," 187. Emphasis added.

${ }^{32}$ Verga, "La Lupa," 189. Emphasis added.

${ }^{33}$ Verga, "La Lupa," 188.

${ }^{34}$ Verga, "La Lupa," 188.
} 
through her behavior, breaks the social expectations of the villagers. The Lupa stands out for her defiance of traditional patriarchal Sicilian social patterns. Throughout the short story, "la Lupa" is alone, an instinctual and uninhibited woman. Her son-in-law and incestuous lover, Nanni, comes across as a passive man who is incapable of exercising his will against his own sexual gain. Since he cannot simply say no to her, to quote Myriam Jehenson, "the Shewolf becomes a 'spell' which he [Nanni] must exorcize through the conventional methods of the village." 35 And very publicly must Nanni repent, having been told to lick the sidewalk near the steps of the main cathedral: "A Pasqua andò a confessarsi e fece pubblicamente sei palmi di lingua a strasciconi sui ciottoli del sacrato innanzi alla chiesa, in penitenza." ${ }^{66}$ This humiliating act, much like a Dantean contrapasso, likely mirrors-this time on soiled cobblestones-his own oral sexual acts on "la Lupa." "La Lupa" has likewise devoured Nanni: she fixes her gaze on him with "la sete che si ha nelle ore calde di giugno," ${ }^{37}$ and she tells him, "'Te voglio! Te che sei bello come il sole e dolce come il miele, Voglio te!" 38 The language used in these examples focuses on the human tongue: "mangiare" and "divorare," much like lovers, but also much like the frightful mythical werewolf.

La Lupa both devours and nurtures- "Aveva soltanto un seno fermo e vigoroso da bruna," ${ }^{39}$ an innuendo both to her past nursing of her daughter, Maricchia, and to her sexual "nursing" of Nanni. Also, much like the she-wolf in the story of Romulus and Remus, Verga's "la Lupa" symbolizes fertility and regeneration.

Gnà Pina "la Lupa" is portrayed as a symbol of life. At the end of the short story, the reader sees her with poppies in hand, her eyes devouring Nanni as she advances towards him, while he carries an axe. One question comes again to the fore: Does she die at the end of the story? In this final scene, it is Nanni who is terrified, not "la Lupa." It is Nanni who stutters his last words. "La Lupa" "still dominates."

With all the above negative considerations in mind, then, does "la Lupa" die at the end of the short story? Do "good girls gone bad" deserve literary death to appease and sanction the moral status quo of an Italian male-dominated, bourgeois readership in the latenineteenth century?

\footnotetext{
${ }^{35}$ Jehenson, "Verga's," 197.

${ }^{36}$ Verga, "La Lupa," 190.

${ }^{37}$ Verga, "La Lupa," 187.

${ }^{38}$ Verga, "La Lupa," 187.

${ }^{39}$ Verga, "La Lupa," 186.

${ }^{40}$ Jehenson, "Verga's," 204.
} 
We shall now turn to Verga's stage version of La Lupa, which ends just as ambiguously as does his short story. In the stage version, at the very end of the play, stuttering Nanni raises the axe against Gnà Pina. In his stage directions, Verga writes of a "scure omicida," 41 but the curtain falls before the purported murder. Is she murdered? Gregory Lucente wrote compellingly, "It would be ... rash to claim that the axe falls, since in both the narrative and the drama that is precisely what does not happen." ${ }^{42}$ Verga, a member of the lower aristocracy in Sicily, lived his whole life, as Lucente pointed out, "at the edge of socially permissible affectivity." ${ }^{43}$ The death of "la Lupa" is never explicitly declared in text-neither in the short story nor in the stage drama. Should the reader reasonably postulate that, in the end, Nanni will be able to resist the temptation of the female body in front of him, when he has not been able to resist it before? In truth, by the end of the narrative, nothing has changed in the pattern of encounters between the two lovers. Nothing in the final words of the text assures the reader that "la Lupa" has died.

So, is "la Lupa's" literary role to destroy Nanni's life, or is her role rather to destroy imposed patriarchal and repressive values against women's sexual expression? At first reading, it seems to be Nanni's independence at stake here. "La Lupa" appears to be what Judith Rudermann calls the "devouring mother," because "[i]n 'La Lupa,' woman's destructive power receives the author's emphasis, as the male protagonist refuses to capitulate to female domination; instead, he retaliates with violence." ${ }^{44}$ However, Gnà Pina is never repentant in the short story. And Nanni is caught, as Freud would point out, in a simultaneous attraction to and repulsion by the mother figure (incestuous mother figure, in this case), which has by now completed its full rotation: the mother-as-nurturer and mother-as-destroyer are but two sides of the same coin. ${ }^{45}$

I shall conclude this study by trying to identify the "good girls" and the "bad girls" in literature. Are their narrative profiles actually clear cut? Do "good girls" go bad, and, if so, according to whose parameters? Is a sexually uninhibited nineteenth-century Sicilian woman a "bad girl" by definition? What if she copulates with a willing male, likely affected by satyriasis himself, who shows over and over a clear

\footnotetext{
${ }^{41}$ Scognamiglio, Come (ri)leggere 'La Lupa,'110.

${ }^{42}$ Lucente, "Ideology," 137.

${ }^{43}$ Lucente, "Ideology," 137.

${ }^{44}$ Ruderman, "Lawrence's," 159-60.

${ }^{45}$ See Ruderman, "Lawrence's," 163.
} 
case of "impotenza morale," ${ }^{46}$ as Chiappelli pointed out? And who gets to decide the literary price which a "good girl" should pay if she does not follow patriarchal societal expectations? Does falling out of her traditional roles make her automatically "bad," even if she has managed to raise a daughter all by herself, works as hard as any man in the fields, and owns her own home? Whose canonical parameters defined women's behavior in Italian nineteenth-century short stories? Why is it that this short story allows Gnà Pina's sexuality to define most of her character, rather than highlighting her overall independence, strength, determination, and self-sufficiency? Is she really a "bad girl" to the extent which Verga and Sicily's coeval patriarchal society would like readers to believe? Because Verga never explicitly lets that axe fall on Gnà Pina, and because neither the short story nor the stage version exhibit her murdered corpse at the end of the story, I submit that in this novella there is much more to "la Lupa's" lasting imprint as a female character than meets the eye. Because the story lacks the explicit murder of "la Lupa," one can only conclude that "la Lupa" lives on, continues to negotiate the village's scapegoating, and leaves behind an assertive, explicit, lasting legacy of womanhood in the ownership of her own body and sexuality.

Brigham Young University 